\title{
KRITIEK TEEN ARTIKEL DRIE VAN DIE APOSTOLICUM; DIE ONTKENNING VAN DIE DOGMA VAN DIE PARTHENOGENESIS
}

\section{DR. P. J. THEO. KOEKEMOER}

Sedert die Reformasie is die leer van die maagdelike geboorte van Jesus van verskeie kante met krag ontken en afgewys as van geen positiewe waarde vir die Protestantse geloof en geloofsbelydenis nie. Dit sal vir ons onmoontlik wees om hierdie bonte verskeidenheid van uiteenlopende beskouings insake die verwerping van die leerstuk, hier weer te gee. Die „Religionsgeschichtliche" skool met sy kenmerkende sogenaamde „Voraussetzunglosigkeit", (waarmee die Bybelse Openbaringsbegrip benader en beoordeel word) met sy pretensie om "suiwer, objektiefwetenskaplik" die ryke hoeveelhede godsdienshistoriese materiaal te verwerk, spreek vanuit die religie in die algemeen. Daardeur kom Jesus te staan op dieselfde lyn as die gode-seuns en helde wat gebore is uit die gemeenskap van die godhede met mensekinders. Die Romeinse-, Egiptiese-, Griekse-, Persiese-, ens. -godsdienste, verskaf materiaal van talle maagdelike geboortes. Die godsdienshistoriese skool met sy ewolusionistiese ontwikkelingsgedagte, wil die christendom die eer bewys deur dit die hoogste plek aan te bied, as die „Höchstellung in der bisherigen Religionsgeschichte". Die aanspraak van die Seun van God, die Christus van die Bybel, het op een lyn te staan gekom naas die aanspraak van ander heilsbrengers en helde-figure. Daarmee is die absoluutheid van die Bybelse Openbaring opgehef. Jesus is gebore uit 'n maagd soos die heilande van die ander godsdienste. Hierdie skool het die maagdelike geboorte van Jesus nie ontken nie, maar gekonstateeer op een lyn met die ander maagdelike geboortes, en so die unicum van die hele Christusopenbaring gerelativeer.

Vandag is dit BULTMANN wat hierdie ,mite" uit die Nuwe Testament wil elimineer. Sy onderneming sal ons straks moet ondersoek.

Die wesenlike ontkenning van hierdie dogma is onderneem deur die Modernisme in verskeie gestaltes. ${ }^{1}$ ) Die "suiwere Evangelie van Jesus" moet so "goed moontlik" aan die lig gebring

1) Vgl. hieromtrent: Prof. H. Windisch: „De Tegenwoordige stand van het Christusprobleem", 2de druk, 1925 bls. 55-68. Ook Albert Schweitzer: „Geschichte der Leben Jesu Forschung”, 4de druk 1926. Uitg. J. C. B. Mohr. Tübingen. 
word. Ons verneem dat 'n Teologie wat „modern” en „histories verantwoord" wil wees, tot taak het om die ,rekonstruksie" van die "verkondiging van Jesus", die ,geloof van die oergemeente" en die "bedoelinge van Paulus" weer suiwer deur te gee $^{2}$ ). In hierdie sin kan Adolf von Harnack praat van ,das Doppelte Evangelium in N. Test. ${ }^{3}$ ). Tipies van die modernistiese resultaat is die volgende: „Aan hierdie voorstelling van die pre eksistente Christus wat van eminente belang geword het vir die klassieke triniteitsleer, is ons egter ontgroei. Dit is vir ons inderdaad mitologies. Ons wêreldbeeld, ons voorstellings-apparaat het egter 'n ander geword .. . "4). Hier kom die gestalte van Bultman vanself na vore. Ook op rasionalistiese gronde is die maagdelike geboorte geskraap en bestempel dat 'n sacrificium intellectus nie daarvoor gebring kan word nie.

Kohnstamm verklaar dat hierdie dogma 'n uiters gevaarlike en onBybelse weg bewandel. As dit so is dat Jesus geen menslike vader gehad het nie, dan staan die menslike vaderskap as sodanig onder die vloek van die sonde, is daar nog net een weg: die Roomskatolieke klooster. Dan is die huwelik en die gesin in sy wese geskend ${ }^{5}$ ). In sy dogmatiese briewe merk Van der Leeuw op: "Wie behoefte heeft aan onbegrijpelijkheden als zoodanig moge de oude mythe handhaven. Wiens denken nog zooveel overeenkomst vertoont met het antieke dat hij de geboorte uit een maagd de vanzelfsprekende vorm vindt voor de nederdaling van God in Jesus Christus, moge bij het oude blijven"6). Hy verwerp egter self hierdie vorm, aangesien hy in ons tyd hierdie „mite" nie meer sprekend en verstaanbaar ag vir die nederdaling van God in hierdie wêreld nie.

$\mathrm{Na}$ al bogenoemde gegewens wat dui op 'n groot hoeveelheid materiaal wat verwerk kan word, lyk dit ons die beste om slegs enkele figure breedvoerig te bespreek:

a) 'n Voorbeeld uit die reformatoriese tyd: Menno Simons.

b) Emil Brunner.

c) Rudolf Bultmann.

2) Dr. J. M. Veen: Art. „De Christologie van het Nieuwe Testament," in die bundel: Christologische Studien." Uitg. Ploegsma, Amsterdam 1943, bls. 62.

3) Gesiteer deur Dr. J. M. Veen, A.W. bls. 62.

1) Dr. J. M. Veen: A.W. bls. 75 vv. Vgl. ook verder die art. van Dr. P. D. Tjalsma: „De Dogmatische Achtergrond eener Vrijzinnige Christologie” in die bundel: „Christologische Stüdien, bls. 132 v.v.

5) Ph. Kohnstamm: Schepper en Schepping, deel 3, „De Heilige” bls. 163179.

6) A. D. R. Polman: Onze Nederlandsche Geloofsbelijdenis, 2de Deel. T. Wever, Franeker, Bls. 258. 


\section{a. Menno Simons. (Die Doperse Rigting).}

By nadere ondersoek blyk, soos dit ook uitdruklik verklaar word in art. 18 van die Nederl. Geloofsbelydenis, dat hierdie artikel bepaald gerig is teen die Wederdopers insake die geboorte van Jesus. Daarom lê dit op ons weg om hier nadere ondersoek te doen. 'n Deel van hierdie artikel lui soos volg:

„... Dewelke eens dienstknechts gestaltenisse aangenomen heeft, en den mensch gelijk geworden is, waarachtelijk aannemende een ware menschlijke natuur, met al haar zwakheden (uitgenomen de zonde), ontvangen zijnde in het lichaam der gelukzalige maagd Maria, door de Kracht des H. Geestes, zonder toedoen ...."

Onder hulle (die Wederdopers), moet veral Menno Simons (1496-1561) genoem word. Hy het hierdie belydenis-artikel as 'n „Antichristische leer" verwerp. Hy gaan uit van die standpunt dat alles wat uit Adam stam, aan die vloek onderworpe is. „Die beweren wil, dat de mensch Christus Jesus vleesch van eender vrouwen, ja Abrahams ende Davids naturelycke Zaedt soude zijn, die alle van Adams onreyn sondelyck zaedt afgekomen zij, die moet oock daarby setten Adams ongerechtigheydt, vloeck ende sonde . . . Daer wyst ons Joannis dat Goddelijk zaet, materie oft wesen aen, daer uyt Godt de Vader de Mensche Christum uyt Maria in der tydt voortgebracht ende gegenereert heeft nl. dat onbevindelijke eeuwige Woort . . Daarom is hij niet van maar in Maria vleesch geworden"i). Teen die Oud-Kerklike belydenis dat die Seun van God, die tweede Persoon van die Drie-eenheid, die ware menslike natuur uit die maagd Maria aangeneem het, het baie doopsgesindes die beswaar dat Christus dan gebore sou wees uit ons onrein menslike vlees en bloed ${ }^{8}$ ). Menno ontken dus in wese dat Christus afstam van Adam, Abraham, Dawid, na die vlees. Die paradysbelofte aangaande die saad van die vrou (Gen. 3:15) moet nie letterlik nie, maar geestelik verstaan word, volgens Menno $^{9}$ ). Die geboorte van Christus word op hierdie wyse gespiritualiseer. Die logiese gevolg hiervan is dan ook te verstaan: hy het in die dwaalleer van die docetisme verval $^{10}$ ) soos duidelik blyk uit die volgende: Christus word wel

7) A. D. R. Polman: Onze Nederlandsche Geloofsbelijdenis. 2de deel, bls. 244. T. Wever, Franeker.

8) Ons sien hierdie opvatting by Menno Simons in die twisgeskryf tussen hom en Martin Micron, na aanleiding van die ontmoeting te Wismar, 1553, Vgl. Dr. J. H. Wessel: De Leerstellige Strijd tusschen Nederlandsche Gereformeerden en Doopgezinden in de zestiende eeuw. Hoofstuk 7, bls. 169-202. Van Gorcum en Comp, N.V., Assen, mcmxLV.

9) Dr. J. H. Wessel: A.W. bls. 171.

10) Dr. J. N. Bakhuizen van den Brink en Dr. J. Lindeboom: Handboek der Kerkgeschiedenis, Deel 2. 2de Druk. D.A. Daamens. Uitg. Mpij. N.V. S'Gravenage 1946, bls. 84, 85. 
die saad van Abraham genoem, sê Menno, maar dit moet in die gees van Gal, 3:16 in geestelike sin opgevat word. Wanneer à Lasco hom op Hebr. 2:16 beroep, dat God nie die engele nie maar die saad van Abraham aanneem en die broeders in alles gelyk geword het, vind Menno dit 'n ,vleeslike" konklusie wat nie strook met Joh. 1:14 nie. Christus is vir Menno „dat Geestelycke beloofde zaadt der nieuwer ende Geestelicker Eva (Gen. 3:15) naamlik de eeuwighe waerheydt (Joh. 14:6), een krachtich Verwinner des Serpent ende zijns zaets" ${ }^{11}$ ).

Calvyn, Bullinger, a Lasco en Micron het hulle met groot beslistheid teen die doperse dwaalleer verset. Guido de Bres het in sy arbeid teen die dopers, nuttig gebruik gemaak van die argumente op Bybelse grond ten gunste van die vere homo ${ }^{12}$ ). Die Wederdopers praat graag van 'n akker waarin die saad gestrooi is. De Bres vra: Waar word die vrou in die Bybel met 'n akker vergelyk? Christus word wel egter die spruit (van 'n boomwortel) genoem. Jes. 11:1. 'n Spruit is uit die substansie van 'n wortel; so is Christus die saad van die vrou ${ }^{13}$ ). Art. 18 van die Nederl. Geloofsbelydenis eindig aldus: „Daarom belijden wij (tegen de Ketterij der Wederdoperen, die loochenen dat Christus menschelijk vleesch van zijne moeder aangenomen heeft), dat Christus is deelachtig geworden des vleesches en bloeds der kindern, dat Hij een vrucht der lendenen Davids is, zooveel het vleesch aangaat; geworden uit het zaad Davids naar het vleesch; eene vrucht des buiks van Maria; geworden uit eene vrouw; eene spruite Davids; eene scheut uit den wortel van Isai; gesproten uit het geslacht van Juda; afkomstig van de Joden, zooveel het vleesch aangaat; uit den zade Abrahams, aangezien hy aangenomen heeft het zaad Abrahams, en is zijnen broederen in alles gelijk geworden, uitgenomen de zonde; alzoo dat $\mathrm{Hij}$ in der waarheid onze Immanuel is, dat is, God met ons". Dit is duidelik waarmee Guido de Brès die waarheid meet, met welke maatstaf hy te werk gaan om te onderskei tussen waarheid en dwaling, geloof en ongeloof: die sola Scriptura!

Die twee-nature-leer van die Kerk aanvaar Simons nie omdat dit sou beteken "... . twee Sonen, ende ghedeelde Christus"14). volgens die Kerklike leer, sê hy, het nie die Seun van God vir ons gesterf nie, maar alleen die seun van Maria. Hy sê: „Onze gront en gelove is, als dat dat selfde woort, wijsheyt, ofte eerstgebo-

11) Vgl. A. D. R. Polman, A.W. Deel 2, bls. 245.

12 ) Vgl. A. D. R. Polman, A.W. Deel 2, bls. 246-251.

13) Vgl. De Heidelbergsche Catechismus als catechetisch leerboek, verklaard en toegelicht door H. H. Barger, bewerkt naar O. Thelemans Handreichung zum Heidelberger Katechismus, 2de nagenoeg onveranderde uitgave, 1940, bls. 251. Uitg. Kemink en Zoun N.V. Utrecht.

14) Dr. J. H. Wessel, A.W. bls. 172. 
renen ghelijk wi bekent hebben, inder tijt vandē Heemel heerafgeauren is, en is door den cracht des alderhoochsten en sijns heyligen geests een waerachtich, lijdlick, sterflick mensche, niet van Maria dan in Maria bouen aller menschen begrijp gheworden, gelijc Johannes secht: Dat woordt is vleysch gheworden"15).

Die doperse Avondmaalsleer (wat hier nie bespreek word nie) toon opvallend dieselfde tendens tot vergeesteliking. 'n Verklaring hiervoor sal seker gesoek kan word in die doopsgesinde spiritualisme en dualisme tussen stof en gees. „Men kan ook vele Dooperschen onder de Spiritualisten rekenen, om hun nadruk op het Inwendig Woord, hun afkeer van uiterlijkheden in eeredienst en Kerkbegrip, hun ijveren voor aanbidding in geest en in waarheid" $\left.{ }^{16}\right)$. Teenoor hierdie afsydigheid en teruggetrokkenheid, hierdie beslotenheid van die doperse rigting, het die Calvinisme die wêreld gesien as die oop terrein en arbeidsveld vir die Kerk, die terrein wat vir Christus verower moet word ${ }^{17}$ ).

KONKLUSIES: Menno Simons is nie sonder meer verkeerd wanneer hy uitgaan van die standpunt dat alles wat uit Adam stam, aan die vloek onderworpe is nie ${ }^{18}$ ). (Vgl. byvoorbeeld ons Doopformulier: "... Ten eerste dat ons met ons kinders in sonde ontvang en gebore word en daarom kinders van die toorn is, sodat ons in die ryk van God nie kan kom nie tensy ons weer gebore word.") Sy dwaling begin egter daar, waar die heidensfilosofiese dualisme tussen stof en gees as deel van die lewensopvatting van Menno Simons, aan hom die bril verskaf waarmee hy die Heilige Skrif lees. Hierdie lewensbeskouing sien die materie enkel as die sondige en daarom as die te vermyde element. So diep kan Jesus Christus nie in die „sarks” (die sondige) betrek word nie. Daarom moet Sy geboorte uit die maagd Maria noodwendig gespiritualiseer word. Hierdie vooraf ingenome filisofie veroorsaak dat sy eksegese onaanvaarbaar word. Hy verval daarmee ook vanself in die eeue oue dwaling van die docetisme waarheen reeds die Johannesbriewe van die Nuwe Testament verwys, waarteen die vere homo leer van die oue Kerk waarskuwend heenwys. Die doperse leer oor Kerk en Staat, hulle lewenshou-

15) Menno Simons: "Gans duytlijck antwoord", gesiteer deur Dr. J. H. Wessel, A.W. bls. 173.

16) Dr. J. N. Bakhuizen van den Brink en Dr. J. Lindeboom. A.W. deel 2. bls. 81 . Vgl. ook: Dr. J. Reitsma: Geschiedenis van de Hervorming en Hervormde Kerk der Nederlanden. Derde, Bijgewerkte en Vermeerderde Druk. Kemink en Zoon, Utrecht, 1916, bls. 213.

1i) Dr. W. F. Dankbaar: Hoogtepunten uit het Nederlandsche Calvinisme in de zestiende eeuw, bls. 169 en 170 . H. D. Tjeenk Willink en Zoon. N.V. Haarlem, 1946.

18) Ons gaan hier nie nader in op die leer van die Erfsonde nie. 
ding en afkeer van die "wêreld", kan in die grond van die saak teruggevoer word tot hierdie filosofie wat op grond van die Skrif onaanvaarbaar is.

Op legitieme wyse, op grond van die reformatoriese sola scriptura, het art. 18 van die Nederl. Geloofsbelydenis, onderskei tussen waarheid en dwaling.

\section{(b) EMIL BRUNNER.}

BRUNNER gee 'n eksplisiete beskouing oor die maagdelike geboorte wanneer hy handel oor die inkarnasie van die ewige Seun van God. Die Skrifbewys vir die menswording sê vir hom niks oor die „hoe” of „hoedanig” die menswording geskied het nie, dit sê alleen dat dit geskied het ${ }^{19}$ ). Die dogmatikus moet hierdie feit in gedagte hou en hom nie te veel oor die „hoe" van cie menswording verdiep nie. Hierteenoor is daar in die Nuwe Testament 'n oorlewering aangaande die "hoe" van die Inkarnasie, naamlik die sogenaamde maagdelike geboorteverhale van Mattheus en Lukas. Hierdie berig het by sekere teoloë en kerklike groepe tot 'n sentrale leer van die christelike geloof geword, aldus Brunner.

Dit gaan by Mattheus en Lukas om die „hoe” van die „ontstaan" van die godmenslike persoon; nie om die "hoe" van die menswording van die ewige Seun van God nie, maar om die „ontstaan" van die persoon, Jesus Christus. Dit is die kerklikeksegetiese harmonistiek wat die leer van die menswording van die Ewige Seun van God in die beide sinoptici „hinein” lees, asof dit hier slegs om 'n presiese beskouing oor die hoe van die mens-wording van die ewige Seun van God gaan ${ }^{20}$ ). Dit gaan by Mattheus en Lukas slegs hierom: hoe die Seun van God, Jesus Christus, verwek is. „Die leer van die menswording van die ewige Seun van God by Paulus en Johannes en die leer van die verwekking van Jesus Christus deur die Heilige Gees in die skoot van die maagd Maria, is twee parallelle, van mekaar onafhanklik, om „das Geheimnis Jesu" te onderstreep" ${ }^{21}$ ). Lukas en Mattheus het volgens BRUNNER nog niks van 'n ewige Seun geweet nie; ,ihr Bericht nimmt seinen Ausgangspunkt bei jenem Stadium der werdenden Christologie, wo man noch nicht von einem ewigen Sohn sprach, wo also das Thema Menschwerdung des ewigen Gottessohnes noch nicht aktuell war"22). Al wat die beide Evangelies doen, is om 'n antwoord te gee op die vraag na

19) Emil Brunner: „Die Christeliche Lehre von Schöpfung und Erlösung”, Dogmatiek, Band 2, Zwingli-Verlag, Zurich 1959, bls. 415, vgl. Rom. 8 v. 3,2 Kor. 8 v. 9 , Phil. 2 v. 6, Joh. 1 v. 14

20) Emil Brunner: A.W. bls. 416 en ,Der Mittler” bls. 288.

21) Emil Brunner: A.W. bls. 416.

22) Emil Brunner: A.W. bls. 416. 
die „Woher" van die Seun van God, Jesus Christus . . . die Seun van God het „gekom" deur sy verwekking (sonder vader) deur die Heilige Gees uit die maagd Maria. Die berigte van Mattheus en Lukas beteken die uitsluiting van die „vorzeitliche Existenz” van die Seun van God; met ander woorde dit is vir BRUNNER duidelik dat by Mattheus en Lukas geen spore is van wat die latere ortodokse teologiese leer van die "asumptio carnis Verbi aeterni" nie. ${ }^{23}$ ).

Wanneer Mattheus en Lukas van die verwekking van die persoon van die Verlosser praat, dan is dit volgens Brunner ' $n$ christologie wat die Kerk nie kan aanvaar nie: Die gedagte dat Jesus Christus as persoon "verwek" is, is 'n idee met ariaanse kleur. Indien die uitdrukking ,verwek" nie ariaans klink nie, maar athanasiaans, is dit ' $n$ blote skyn. Volgens Mattheus en Lukas word Jesus Christus deur God gemaak in die tyd, uit die skoot van die maagd $^{24}$ ).

BRUNNER wys op die ,argumentum e silentio" van die res van die Nuwe Testament en konkludeer daaruit: „Die Lehre von der Jungfraulichen Geburt gehört also nicht zum Kerygma der neutestamentlichen Kirche ..." ${ }^{25}$ ). Hierdie Nuwe Testamentiese feit dat die maagdelike geboorte in die res van die Nuwe Testament of onbekend of geignoreer is, en in die prediking van die apostels nie die minste ' $n$ rol speel nie, staan in teenstelling met die dogmatiese feit, dit wil sê die opname in die sogenaamde apostoliese geloofsbelydenis, en daarom deel van die Kerklike leer en vanselfsprekende bestanddeel van die Kerklike prediking ${ }^{26}$ ).

Ook die mening as sou die maagdelike geboorte 'n besondere steun vir die sentrale leer van die Nuwe Testament naamlik vir die Inkarnasie wees, is vals, sê BRUNNER. Dit is 'n feit dat baie christologiese ketterye soos die adopsianisme van Paulus van Samosata en die Arianisme met hierdie leer verbind was. Ook diegene wat die Godheid van Christus loën, het aan hierdie leer geglo. Daarom is volgens Brunner, niemand geregtig om die leer van die maagdelike geboorte tot kriterium van die ware geloof aan die godheid van Jesus te maak nie. Mens kan ook sonder die leer van die maagdelike geboorte aan die Godheid van Jesus Christus glo, beweer BRUNNER ${ }^{27}$ ).

2s) Emil Brunner: A.W. bls. 417.

24) Emil Brunner: A. W. bls. 417.

25) Emil Brunner: A.W. bls. 418 en „Der Mittler” bls. 288.

26) Emil Brunner: A.W. bls. 418 v.v.

27) Emil Brunner: A.W. bls. 419. 
Die leer van die maagdelike geboorte staan ook in stryd met die leer van die ware mensheid van Jesus Christus. Kan 'n vaderloos-verwekte 'n ware mens wees? $\mathrm{Hy}$ is dan nie gebore soos ons ander mense nie. Daar lê 'n sterk docetiese trek in hierdie leer en 'n negatiewe waardering van die geslagtelike verwekking, wat meer die vertolking is van 'n hellenisties-asketiese as 'n Bybelse skeppingsgedagte, meen BRUNNER. Asketiese en geslagsvyandelike strominge het agter hierdie leer skuilgegaan; dit het 'n hoof steunpilaar vir die gans onbybelse Mariaverering geword ${ }^{28}$ ).

Met die historiese getuienisse aangaande die maagdelike geboorte staan dit derhalwe uiters swak: Die stamboom wys op die manlike verwekker; die res van die ganse Nuwe Testament swyg hieroor; die waarskynlikheid van die inwerking van die verkeerde vertaling in die LXX van Jes. 7 v. 14; die lesing van die Sirus Sinaiticus; die pauliniese ,gebore uit die geslag van Dawid na die vlees"; die legendariese trekke ens., is gewigtige getuienisse teen die geloofwaardigheid van die maagdelike geboorte ${ }^{29}$ ).

Die grootste wonder van die menswording wat die apostel verkondig, is nie dat die Seun van God uit 'n maagd gebore is nie, maar dat die Ewige Seun van God wat van ewigheid af in die skoot van die Vader was, ongeskape, uit die wese van God voortgekom, mens geword het; dat $\mathrm{Hy}$, die Ewige en persoonlike Woord van God in Jesus Christus as mens van ons vlees en bloed ons as Heer tegemoet tree . . . as die Verlosser, deur wie ons versoening en vrye toegang tot God, ware Godkindskap deelagtig word indien ons in $\mathrm{Hom}_{\mathrm{glo}^{30}}$ ).

BRUNNER gee toe dat die „voorstelling” van die maagdelike geboorte 'n heilsame invloed uitgeoefen het ,als erster Versuch der Urchristenheit, das Geheimnis der Person Jesu zu verkünden". Jesus is so „van natuur" God. Die stryd teen hierdie leer word daarom ook gevoer deur diegene wat aan Sy godheid nie glo nie, naamlik die moderne adopsianisme, wat BRUNNER „teologiese liberalisme" noem ${ }^{31}$ ).

Die leer van die maagdelike geboorte sou volgens BRUNNER lankal verval het, indien daar nie skynbare sterk dogmatiese gronde aanwesig was nie ${ }^{32}$ ) naamlik veral die heenwysing na die

28) Emil Brunner: „Der Mittler” bls. 290: „Zu einem menschlichen Leben gehört die zweigeschlechtige Zeugung".

29) Emil Brunner: A.W. bls. 420 en „Der Mittler” 288-292.

30) Emil Brunner: A.W. bls. 421.

31) Emil Brunner: A.W. bls. 421-422.

32) Emil Brunner: „,Der Mittler”, bls. 289, „Es spricht im Gegenstand alles dafür, dass diese Lehre ziemlich spät aufgekommen ist, also nicht einem geschichtlichen Wissen von einen Vorgang, sondern dogmatischen Motiven entsprungen sei". 
leer van die erfsonde. Hierdie verbinding tussen maagdelike geboorte en sonder erfsonde is nie te aanvaar nie. Dit is nie in te sien nie, sê BRUNNER, "warum die zweigeschlechtige Erzeugung für Gott ein Hindernis gewesen sein sollte, einen sündlosen Gottmenschen zu erschaffen"33).

Die voorstelling van die parthenogenesis is volgens BRUNNER 'n poging om die wonder van die inkarnasie biologies te verklaar. Daarom wys hy dit af: „Nicht weil wir das Wunder einer eingeschlechtlichen Zeugung nicht für möglich hielten, sondern weil wir diese biologische Neugier als nicht zur Sache gehörig be-urteilen und erkennen, dass das Zeugnis der Apostel uns in diesem Urteil recht gibt; darum lehnen wir diese Lehre unsererseits $a b$, ohne sie zu bekämpfen" ${ }^{34}$ ). BRUNNER wil slegs die sentrale wonder van die inkarnasie onaangetas laat. „Das majestätliche Wunder der Menschwerdung des Gottessohnes wird durch die biologische Theorie der eingeschlechtigen Zeugung nicht grösser, sondern kleiner gemacht"'35).

Dit gaan nie om die "hoe" van die inkarnasie nie, maar om die "dat" van die wonder, in streng Paulinies-Johanneise sin. Die „dat" wys op die saak, die ,hoe” op die „vorm”. BRUNNER wil nie die „saak" prysgee nie, maar wel die „vorm".

\section{Kritiese Beskouing:}

Teenoor BRUNNER is eksegese aan te toon dat Josef nie die ,biologiese vader" van Jesus is nie, maar deur adopsie die legale vader; dat dit daarom niks aan die maagdelike geboorte afbreek wanneer gepraat word van „sy ouers" of „sy vader" nie. BRUNNER het hom geensins vergewis van die lesing van die Sirus Sinaiticus nie; vandaar dat hy dit in aanmerking neem wanneer hy sy besware teen die maagdelike geboorte opsom. Die Sirus Sinaiticus is nie met die maagdelike geboorte in stryd nie. Op grond van die vroegste leer van die Kerk (byvoorbeeld die patres en die Romeinse simbool), het die parthenogenesis wel die reg op sy plek in die apostolicum.

Wanneer Karl BARTH handel oor „Das Geheimnis der Offenbarung" en daaronder die leer van die maagdelike geboorte bespreek, dan tref sy kritiek veral BRUNNER se beskouing. BARTH verwys na die ou en beslissende geskilpunt tussen hom en BRUNNER wanneer hy die vraag stel: Is dit toevallig dat by diegenes wat hierdie teken loën, daar op een of ander wyse 'n ,natuurlike teologie" insluip? Daar bestaan fakties 'n fatale samehang tussen die ,aanknopingspunt” en die loëning van die maag-

33) Emil Brunner: „Der Mittler”, bls. 291.

34) Emil Brunner: "Der Mittler", bls. 291 v.v.

35) Emil Brunner: „Der Mittler”, bls. 290. 
delike geboorte. BRUNNER beweer dat mens die godheid van Jesus Christus kan bely sonder die geloof aan die maagdelike geboorte. BARTH stel die saak so: Niemand kan die geheimnis van die Persoon van Jesus Christus werklik erken en dus werklik glo, wanneer hy die maagdelike geboorte loslaat nie ${ }^{36}$ ).

BARTH noem die hoofstuk handelende oor die maagdelike geboorte in BRUNNER se „Der Mittler”, „merkwaardig”! BRUNNER opper die beswaar wat alle ander sedert Schleiermacher ook gesê het: die leer van die maagdelike geboorte beteken 'n biologiese interpretasie van die wonder van die inkarnasie, 'n verklaring van die goddelike wonder in sy "hoe"? Daarteenoor wil BARTH eksegeties opmerk wat Martin Dibelius reeds gesê het: 'n Biologiese "verklaring" van die inkarnasie is nog in die Nuwe Testament, nog in die simbool ${ }^{3 i}$ ).

BRUNNER wil nie die „saak”, die Inkarnasie, prysgee nie, maar wel die „vorm" waarin dit by Mattheus en Lukas verskyn, naamlik die „vorm" van die maagdelike geboorte. Maar is die uiterlike vorm waarin die openbaring volgens die Bybelse getuienis sigbaar en hoorbaar word, 'n blote toevalligheid? Is hy wat die "teken", die „vorm" loën nie ook besig om die saak te loën nie? $\left.{ }^{38}\right)$.

„BRUNNER se bestryding van die maagdelike geboorte is geen goeie onderneming nie”, sê BARTH. „Dit brei, soos dit ook by ALTHAUS die geval is, uit oor sy ganse Christologie". Die teleurstelling van N. Berdjajev is ook BARTH se teleurstelling: „Ek het die boek van BRUNNER met groot belangstelling gelees terwyl ek die spanning en die skerpte van die gedagtes, die religieuse pathos daarin gevoel het. Maar toe ek by die plek kom waar BRUNNER sê dat hy nie aan die maagdelike geboorte glo nie, was ek treurig gestemd; dan is dit of alles geskraap word, of alles verder doelloos is ${ }^{39}$ ).

\section{(c). R. BULTMANN.}

„Want ons het nie verdigte fabels nagevolg toe ons julle die krag en koms van onse Here Jesus Christus bekend gemaak het nie, maar ons was aanskouers van Sy majesteit, want Hy het van God die Vader eer en heerlikheid ontvang toe hierdie stem na Hom gekom het van die luisterryke heerlikheid: Dit is my geliefde Seun in wie ek 'n welbehae het". II Petr. 1 v. 16 en 17.

36) K. Barth: K.D. I, 2 bls. 200 v.v.

3i) K. Barth: K.D. I, 2 bls. 200 v.v.

38) K. Barth: K.D. I, 2 bls. 211.

39) K. Barth: K.D. I, bls. 211. 


\section{A. Sy Teologiese Beskouing:}

BULTMANN verklaar: „Die Legenden von der Jungfrauengeburt und von der Himmelfahrt Jesus begegnen nur vereinzelt. Paulus und Johannes kennen sie nicht"40), en verder: „ebenso widerspricht die Vorstellung von der Jungfrauengeburt den gedanken seiner Praexistenz"41).

Hierdie opmerkings van BULTMANN aangaande die maagdelike geboorte is 'n konsekwente afleiding uit sy hele teologiese visie: die „Entmythologisierung” van die christelike geloof. Dit sal nodig wees om kortliks aan te toon dat sy beskouing aangaande die maagdelike geboorte inpas in die hele teologiese denke van BULTMANN.

Vir BULTMANN is dit 'n uitgemaakte saak: „Das Weltbild des Neuen Testaments ist ein mythisches ... Dem mythischen Weltbild entspricht die Darstellung des Heilsgeschehens das den eigenliche Inhalt der neutestammentlichen Verkundigung bildet". BULTMANN wys duidelik wat die mitologiese spreekwyse van die Nuwe Testament is: „In mythologischer Sprache redet die Verkundigung: Jetzt ist die Endzeit gekommen: als die Zeit erfüllt war, sandte Gott seinen Sohn. Dieser, ein praexistentes Gottwesen, erscheint auf Erden als ein Mensch, sein Tod am Kreuz, den er wie ein Sünder erleidet, schaft Sühne für die Sünden der Menschen. Seine Auferstehung ist der Beginn der kosmischen Katastrophe, durch die der Tod, der durch Adam in die Welt gebracht wurde, zunichte gemacht wird, die dämoni schen Weltmächte haben ihre Nacht verloren. Der Auferstandene ist zum Himmel erhöht worden zur Rechten Gottes; er ist zum „Herrn” und „König” gemacht worden. Er wird wiederkommen auf den Wolken ..." "42).

Bogenoemde is vir BULTMANN mitologiese spreke en is terug te voer op die ,zeitgeschichtliche” mitologie van die Joodse apokaliptiek en die gnostiese verlossingmites ${ }^{43}$ ). Die mitologiese spreke is vir die mens van vandag nie te aanvaar nie omdat vir hom die mitiese wêreldbeeld iets van die verlede is. Die vraag van die verkondiging van die Nuwe Testamentiese waarheid is van die mitiese wêreldbeeld onafhanklik. Daarom is dit die taak

40) Rudolf Bultman: „Neues Testament und Mythologie, Das Problem der Entmythologisierung der Neutestamentlichen Verkundigung" in die Bundel „Kerygma und Mythos" herausgegeben van H. W. Bartsch, Uitg. Heich \& Heindrich, Hamburg, 1948, bls. 22.

41) Rudolf Bultmann: do. bls. 24.

42) Rudolf Bultmann: Neues Testament und Mythologie, bls. 15 en 16 .

43) Rudolf Bultmann: do. bls. 16. Vgl. ook R. Bultmann:: "Jesus" bls. 19-26. Rudolf Bultmann: „Theologie des Neuen Testaments" Deel $I$, Tubingin, 1948. Uitg. J. C. B. Mohr) bls. 163-182 insake die gnostiese motiewe. 
van die teologie om ,die christliche Verkündigung zu entmythologisieren"44).

Dit is sinloos en onmoontlik indien die prediker die mitiese wêreldbeeld van die Nuwe Testament aan die mens van vandag, as waarheid voorhou ${ }^{45}$ ). Waarom is dit onmoontlik? BULTMANN antwoord: "... nachdem unser alles Denken unwiderruflich durch die Wissenschaft geformt worden ist" ${ }^{16}$ ). Die natuurwetenskaplike wêreldbeeld het die mitiese wêreldbeeld onmoontlik gemaak.

Dit gaan vir BULTMANN egter nie slegs om die natuurwetenskaplike beeld nie, maar ,,im Grunde noch vielmehr um die Kritik, die aus dem Selbstverständnis des modernen Menschen erwächst" . . . dit gaan vir die moderne mens daarom „dass er sein Leben rational organisieren kann" ${ }^{47}$ ).

Wanneer BULTMANN in hierdie verband die "legende" van die maagdelike geboorte noem, wys hy daarop dat nie alle mitologiese uitsprake in die Nuwe Testament dieselfde aksent dra nie; voorbeelde is die legende van die maagdelike geboorte en die Hemelvaart van Christus. Ook al sou hierdie „legendes" as 'n latere toevoeging beskou word dan behou die Heilsgebeure nog sy mitiese karakter ${ }^{48}$ ).

Die sinloosheid van die mite vind BULTMANN daarin dat dit spreek ,van die mag of magte wat die mens meen te aanvaar as grond en grense van sy wêreld en sy eie handeling"49). Hierdie magte kom binne die kring van die bekende wêreld en die menslike lewe met sy moontlikhede. „Im Mythos findet der Glaube ausdrück, dass die bekannte und verfügbare Welt, in der der Mensch lebt, Grund und ziel nicht in sich selber hat, dass vielmehr ihr Grund und ihre Grenze ausserhalb des bekanten und Verfügbaren liegen, und dass dieses Bekannte und Verfügbare ständig von den unheimlichen Mächten, die ihm Grund und Grenze sind, durchwaltet und bedroht ist. Und in eins damit gibt der Mythos dem Wissen ausdrück, dass der Mensch nicht Herr seiner selbst ist $\ldots .^{50}$ ). Die mens is nie sy eie heer wanneer hy van hierdie vreemde magte afhanklik is nie!

44) Rudolf Bultmann: „Neues Testament und Mythologie” bls. 16.

45) Rudolf Bultmann: do. bls. 17, "Sinlos; denn das mythische Weltbild ist als solches gar nichts spezifisch Christliches, sondern es ist einfach das Weltbild einer vergangenen Zeit, das noch nicht durch wissenshaftliches Denken geformt ist".

46) Rudolf Bultmann: „Neues Testament und Mythologie” bls. 17.

4i) Rudolf Bultmann: "Neues Testament und Mythologie" bls. 19.

48) Rudolf Bultmann: "Neues Testament und Mythologie” bls. 22.

49) Rudolf Bultmann: "Neues Testament und Mythologie” bls. 23.

si) Rudolf Bultmann: "Neues Testament und Mythologie” bls. 23. 
BULTMANN wil duidelik wees wanneer hy beweer dat hy die mite nie verstaan in die moderne $\sin$ van die woord nie, waarvolgens dit nie meer as ,ideologie" beteken nie. BULTMANN spreek aangaande die mite in die sin van die "Religionsgeschichte": Mythologisch ist die Vorstellungsweise, in der das Unweltliche, Göttliche als Weltliches, Menschliches, das Jenseitig als Diesseitiges erscheint ..." ${ }^{51}$ ).

In die mitologiese voorstellingswêreld van die Nuwe Testament is ook enkele voorstellinge wat mekaar weerspreek, onder andere die maagdelike geboorte en preëksistensie van Jesus Christus. So deurtrek is die Nuwe Testament van hierdie weersprekings dat BULTMANN beweer: ,das ein eigentümlicher Widerspruch das Neue Testament als ganzes durchzieht ${ }^{52}$ ).

BULTMANN mag op een punt nie misverstaan word nie: Hy wil die „mitologie” van die Nuwe Testament nie krities elimineer nie maar krities interpreteer. Hy wil nie byvoorbeeld die „mite” as "Zeitgeschichte" so afskil dat slegs die „idee" van die sedelikheid ens., oorbly om daarin die wesenlike van die Kerugma te sien nie. Dit is dit fout van HARNACK dat hy die Kerugma as gevolg van bepaalde religieuse en sedelike grondgedagtes gaan reduseer het tot 'n religieus gemotiveerde idealistiese etiek; ook die interpretasie van die Godsdiens-historiese skool het die kerugmatiese karakter van die Nuwe Testamentiese verkondiging geen reg aangedoen nie, beweer BULTMANN ${ }^{53}$ ). BULTMANN stel: „Die Forderung einer existentialen Interpretation der mythologischen Begrifflichkeit" ${ }_{51}$ ). Die mitologie van die Nuwe Testament moet eksistensieel interpreteer word. Die antropologie van die Nuwe Testament moet aan die moderne mens sy „Existenzverständnis" verduidelik. Die vraag is of hierdie mens in die Nuwe Testament ,ein Verständnis seiner selbst entgegengebracht wird, das ein echte Entscheidungsfrage für ihm bedeutet" ${ }_{55}$ ). Die heilsgebeure moet dan geen mirakel of supra-naturale gebeure wees nie maar 'n historiese gebeure in die tyd en ruimte. Die Woord van God is die nugtere verkondiging van die persoon

51) Rudolf Bultmann: „Neues Testament und Mythologie” bls. 23.

52) Rudolf Bultmann: "Neues Testament und Mythologie" bls. 24.

53) Rudolf Bultmann: "Neues Testament und Mythologie” bls. 26.

54) Rudolf Bultmann: "Neues Testament und Mythologie” bls. 27.

55) Emil Brunner: "Dogmatik", Band 2, bls. 314 vgl. die eksistensiële interpretasie van Bultmann met sy eie begrip ,Wahrheit als Begegnung". Rudolf Bultmann: "Neues Testament und Mythologie" bis 28. Vgl. ook G. Harbsmeier, "Mythos und Offenbarung” in die bundel „Keryg. ma und Mythos" bls. 54: „Bezeugt wird ein Geschehen, Ereignisse, die die Zeugen van aussen her treffen und mehr noch, die an den Zeugen selbst geschehen sind. Das Ereignis liegt nicht im Blickfeld, wenn es nicht das an mir geschehene Ereignis ist". 
van Jesus van Nazareth as werklik historiese mens in sy heilshistoriese betekenis ${ }^{56}$ ). Die mens, ook Jesus van Nazareth, is vir BULTMANN ,ein Stück der Geschichte”: „Nur wenn man bereit ist, den Anspruch der Geschichte zu hören, versteht man überhaupt, warum es sich in der Geschichte handelt . . . also zu einer Geschichts-Betrachtung will ich den Leser im Grunde nicht führen, sondern zu einer höchst personlichen Begegnung mit der Geschichte"57).

Wanneer BULTMANN oor Jesus praat dan wil hy elke „Jenseits" van die geskiedenis vermy en hom bepaal by die „,innerhalb" van die geskiedenis. Daarom is dit te begryp dat die bowe-natuurlike geboorte nie ter sake is nie.

Om ' $n$ betroubare historiese beeld te kry, eis BULTMANN dat met die bronne versigtig te werk gegaan moet word. „Was uns die Quellen bieten, ist ja zunächst die Verkündigung der Gemeinde ..." Laasgenoemde is egter geen bewys dat alle woorde wat Jesus in die mond gelê word, werklik deur Hom gespreek is nie. „Bei vielen Worten lässt sich der Nachweis führen, dass sie vielmehr erst in der Gemeinde entstanden sind, bei anderen, dass sie von der Gemeinde bearbeitet sind"'58). BULTMANN erken egter dat hierdie onderskeiding in die Sinoptici in menig opsig moeilik en vaag is; wat die Johannes-evangelie betref kom dit vir die verkondiging van Jesus nie ter sprake nie! $\left.{ }^{59}\right)$.

Welke maatstaf gebruik BULTMANN wanneer hy genoemde skeiding wil aanbring? „Die Trennung jeder Schicht in den synoptischen Evangelien nun geht zunächst von der Tatsache aus, dass diese Evangelien griechisch innerhalb des hellenistischen Christentums verfasst sind, während Jesus und die älteste Gemeinde in Palăstina ihren Platz hatten und aramäish sprachen. Alles, was in den Synoptikern aus sprachlichen oder sachlichen Gründen nur im hellenistischen Christentum entstanden sein kann, scheideit deshalb als Quelle für die Verkündiging Jesu aus"'0). 'n Kritiese analise toon aan dat 'n wesenlike deel van die sinoptici uit die aramese oorlewering van die oudste Palestynse gemeente oorgeneem is, wat dus geld as bron vir die verkondiging van Jesus. Maar in hierdie laasgenoemde aramese oorlewering is daar weer verskillende stukke, wat 'n gemeentelike kleur of die tekens van 'n voortgaande ontwikkeling dra en derhalwe as

56) Rudolf Bultmann: „Kerygma und Mythos” bls. 52 .

5i) Rudolf Bultmann: „Jesus" Uitg. J. C. B. Mohr, Tubingen, 1951, bls. 7 en 10.

58) D. Rudolf Bultmann: Jesus, bls. 14 .

59) D. Rudolf Bultmann: Jesus, bls. 15.

60) D. Rudolf Bultmann: Jesus, bls. 15 . 
„,sekundär ausgeschieden werden muss"'11). Deur middel van die kritiese analise kom mens tot die "oudste" gedeeltes. Dan verklaar BULTMANN: „Natürlich hat man erst recht keine Sicherheit, dass die Worte dieser ältesten Schicht wirklich von Jesus gesprochen sind"'s2). Die moontlikheid bestaan dat ook die ontstaan van die oudste stuk op 'n gekompliseerde historiese proses teruggaan - 'n proses wat nie meer te bespeur is nie. Maar nieteenstaande hierdie twyfel is daar een feit wat nie te betwyfel is nie: Jesus het werklik geleef. „Dass er als Urheber hinter der geschichtlichen Bewegung steht, deren erstes greifbares Stadium die älteste palästinensische Gemeinde darstellt, ist vollig deutlich"'s3). Dit is egter 'n ander vraag vir BULTMANN, in hoeverre die gemeente ' $n$ beeld van Jesus en Sy verkondiging objektief trou bewaar het. Dit is die gedagtekompleks wat in elke "oudste" stuk oorlewering lê, wat BULTMANN wil ondersoek in die „Begegnung mit der Geschichte"6t). So kom BULTMANN tot die konklusie dat van Jesus geen metafisiese wese gemaak mag word nie omdat nog Hyself nog die oudste gemeente dit doen. Die Griekse christendom het hom tot "Seun van God" gemaak en hom 'n goddelike natuur toegeken „die ihm selbst so fremd wie möglich war"'s5).

In sy kritiese analiese van die Sinoptiese evangelie het BULTMANN uitvoerig aangetoon waar en hoe hy die skeiding maak tussen die woorde van Jesus aan die eenkant en „Wundergeschichte" en "legendes" aan die ander kant $\left.{ }^{66}\right)$. Die christelike gemeente was oortuig dat Jesus wonders gedoen het en verhaal 'n wondergeskiedenis. „Die meisten dieser in den Evangelien enthaltenen Wunderberichte sind legendarisch ... " Deur sy krities-analitiese metode is dit vir BULTMANN moontlik om te verklaar: „Es liegt nun nicht viel daran, genauer zu untersuchen, wieviel von den evangelischen Wunderberichten historisch ist" ${ }^{\prime 67}$ ).

Heeltemal onhistories is vir BULTMANN die "legende". Die maagdelike geboorte, (Matth. 1 v. 18-25 en Lukas 1:26-38) is vir hom 'n legende ${ }^{68}$ ). Hy wys daarop dat dit onmoontlik is om 'n Semitiese berig as grond en oorsprong vir die maagdelike geboorte aan te neem ${ }^{69}$ ). Dit het eers tydens die hellenistiese

61) D. Rudolf Bultmann: Jesus, bls. 15.

62) D. Rudolf Bultmann: „Jesus” bls. 15 .

63) D. Rudolf Bultmann: "Jesus" bls. 15.

64) D. Rudolf Bultmann: ,Jesus" bls. 16.

65) D. Rudolf Bultmann: ,.Jesus" bls. 180.

66) D. Rudolf Bultmann: „Die Gescichte der Synoptischen Tradition" zweite neubearbeitete Auflage. Göttingin, 1931.

67) D. Rudolf Bultmann: ,Jesus" bls. 146-147.

68) D. Rudolf Bultmann: „Die Geschichte der Synoptischen Tradition” bls. 316 en 321 .

69) D. Rudolf Bultmann: do. bls. 316. Bultman beroep hom hier op Klostermann, Leisegang en Strack-Billerbeck. 
„omvormings" die Evangelies binnegekom; op hellenistiese bodem is die gedagte van die verwekking van 'n koning of held deur die godheid uit 'n maagd bekend ${ }^{70}$ ). „Die oudste geskiedenis het slegs verhaal dat 'n engel aan Josef belowe het dat sy seun die Messias sal wees. Daarom is dit so dat Josef uitdruklik as ,.seun van Dawid" aangespreek word.

Om begripsduidelikheid te kry moet ons nog vasstel wat BULTMANN verstaan onder „Wonder”, „Legende” en „Mirakel”.

(a) 'n Wonder is 'n daad van God (die godheid of gode) in onderskeid met 'n gebeure wat uit natuurlike oorsake of menslike wil en dade spruit.

(b) 'n Wonder is 'n wonderbaarlike gebeure (Ereignis), contra naturam. Onder "natuur" word hier verstaan die in reelmatige orde verlopende natuurlike gebeure ${ }^{21}$ ).

'n Misverstand ontstaan wanneer elke wêreldgebeure as daad van God gesien word en so die verskil tussen wêreldgebeure en daad van God prysgegee word. 'n Misverstand onstaan ook wanneer met die wonder slegs verstaan word: 'n „bowe of antinatuurlike gebeure" wat op God teruggevoer word, in die sin dat God slegs die bowenatuurlike veroorsaker is, sonder om die gebeure (Ereignis) as daad van God te verstaan; laasgenoemde is 'n mirakel ${ }^{22}$ ).

Dit is die mirakelgedagte wat vir die mens van vandag onmoontlik geword het. Vir die hede is die „Naturgeschehen” die wetmatige gebeure. Die wonder as deurbreking van die wetmatige samehang van die natuur is vir die moderne mens nie aanvaarbaar nie, omdat die gedagte van die wetmatigheid van die natuur "mit unserem Dasein in der Welt" gegee is ${ }^{73}$ ).

Die „Legendes" "7) is vir BULTMANN ,die erzählende Stücke der Tradition, die nicht eigentlich Wundergeshichten sind, aber doch auch keinen geschichtlichen, sondern religiös erbaulichen Charakter haben". Die "legende" word negatief gekarakteriseer

70) D. Rudolf Bultmann: do. bls. 317 voetnoot beroep hom op: $\mathbf{H}$. Peterson: „Die Wunderbare Geburt des Heilandes", 1909; H. Gunkel: „Zum Religionsgeschichtl. Verständnis des N.Ts.” 2. 1910 bls. 65. Usener: „Das Weihnachtsfest", 1911, bls. 71-78. A. Steinmann: Die Junfrauengeburt und die vergl. Religionsgeschichte 1919. W. Bousset: "Kyrios Christos" 2, 1921, bis. 268-270. H. Leisegang: „Pneuma Hagion", 1922, bls. 14-72. Ed. Norden: „Die Geburt des Kindes” 1924, bls. 76-116. J. G. Machen: "The Virgin Birth of Christ", 1930.

71) Rudolf Bultmann: "Glauben und Verstehen" Gesammelte Aufsätze, Tubingen 1933, bis." 214 v.v. (Uitg. J. C. B. Hohr), Tubingen.

:2) Rudolf Bultmann: „Glauben und Verstehen” bls. 214 tot 217 . „Der Christliche Glaube scheint also am Mirakel nicht interessiert zu sein; er scheint vielmehr Anlass zu haben den Gedanken des Mirakels auszuscheiden".

73) Rudolf Bultmann: do. bls. 215.

74) Rudolf Bultmann: „Die Geschichte der synoptischen Tradition”, Bls. 260. 
as „Ungeschichtlichkeit”, „,kein besonderes Interesse am Geschichtlichen" en geen historiese berig in die moderne wetenskaplike sin van die woord nie ${ }^{75}$ ). Dit is hier waar BULTMANN die maagdelike geboorte plaas; nader bepaald sal hy dit kwalifiseer as „biografiese legende” omdat dit in verband staan met die lewe van die "religieuse heros" ${ }^{\prime 6}$ ).

Wat die Lukaniese berig van die maagdelike geboorte betref, hou BULTMANN 1 v. 34-37 nadruklik vir 'n latere invoeging, 'n "Christlicher Zusatz" wat sy oorsprong het in dieselfde sfeer van hellenistiese Christendom as Mt. 1 v. 18-25. As grond voer hy aan dat die vraag van Maria, (v. 34) as bruid, onverstaanbaar is en geen $\sin$ het nie $^{77}$ ).

Wanneer BULTMANN spreek aangaande die „ontwikkeling” van die Christologie van die Nuwe Testament dan sien hy in die gang van die begrippe Messias, Seun van God, Mense-seun, Kurios, Logos en die verhale van die bowenatuurlike geboorte „nichts spezifisch Christliches" maar slegs die proses waarin die oue mitologie op 'n konkrete menslike gestalte oorgedra is ${ }^{78}$ ).

\section{(B) Kritiese Beskouing:}

In die „gesprek" wat aan die gang gesit is deur die radikale eis van die „Entmythologisierung" van BULTMANN, is stemme van kritiek en waardering gehoor. Die Teologiese fakulteit van die Universiteit van Tübingen het 'n kort samevatting van so ' $r$ kritiese-waardering die lig laat sien. Hierin word daar gewys op verskillende tendense in die teologie van BULTMANN:

(1) Sy aansluiting aan die Eksistensie-filosofie: ${ }^{79}$ ) Luther, A. Schlatter en K. Barth het tereg gewaarsku teen 'n verbondsluiting tussen teologie en filosofie. Die vorige eeu het getoon hoedat die teologie daar uitsien as dit oorgelewer word aan die filosofiese sisteme van die Romantiek, HEGEL en KANT. By BULTMANN verskaf die Eksistensiefilosofie die fundament vir die verstaan van die Nuwe Testament. „Es wird hier zum mindesten nicht nur ausgelegt, nicht nur gehört, was der Text sagt, sondern immer zugleich auch etwas von den mit herzugebrachten philosophischen Voraussetzungen in ihn hineingelegt und dadurch sein Inhalt verändert. Es liegt bei ihm eine Verkürzung der

75) D. Rudolf Bultmann: „Die Gesch. der Synoptische Tradition” voetnoot Bls. 260 .

78) D. Rudolf Bultmann: Die Gesch. der Synoptische Tradition" Bls. 260.

77) D. Rudolf Bultmann: „Die Gesch. der Synoptische Tradition” Bls. 321.

78) D. Rudolf Bultmann:" "Die Christologie des Neuen Testaments" in „Glauben und Verstehen” bls. 247.

79) Sammlung Gemeinverständlicher Vorträge und Schriften aus dem Gebiet der Theologie und Religionsgeschichte 198, 199. „Für und wider Bultmann", Denkschrift der Ev. Theol. Fakultät, Tübingen 1952, bls. 20-27 vgl. ook Emil Brunner, „Dogmatik”, Band 2, bls. 313. 
neutestamentlichen Verkündigung vor. Aus dem unerschöpflichen Reichtum der Welt-und Lebensbezüge, in denen dort die Bedeutung der Erlösung in Christus gepriesen wird, zeigt sich in der Perspektive BULTMANNS nur ein schmaler, um nicht zu sagen: ärmlicher Auschnitt"'80).

(2) Sy „Entmythologisierung” van die Nuwe Testament: „Entmythologisierung" beteken dat onderskeid gemaak moet word tussen die Woord van God en die histories-bepaalde mensewoord, tussen Evangelie en die antieke denkvorme waarin die Nuwe Testament ingebed is. Die eksegeet moet die uitsprake van die Nuwe Testament-uitsprake in die denkvorme van vandag uitspreek. Die radikale wyse egter, waarop BULTMANN die Nuwe Testament-uitsprake ,in den Strudel der Entmythologisierung" geplaas het, staan op een lyn met die uiterste liberalisme ${ }^{81}$ ). BULTMANN pas die maatstawwe van die immanentkousale „Geschichtdenken' 'en die moderne natuurwetenskap toe op die waarheidsgehalte van die Nuwe Testament: „So ist Entmythologisierung nichts anderes als Rationalisierung"s2). Andere meen dat die „Entmythologisierung" beteken 'n radikale ,inkrimping" waarin daar slegs die punctum mathematicum van die eksistensie voor God oorbly. BULTMANN het egter verklaar dat hy nie die mite wil elimineer nie maar interpreteer. Dit kom egter nie daarop aan hoe hy dit bedoel nie; in die praktyk het dit gewys dat die „Entmythologisierung” „eine der unglücklichsten Schöpfungen BULTMANNS ist. Es hat viel zur Verwirrung und zum Missverständnis beigetragen, weil der in ihm enthaltene Begriff von "Mythos" ungeklärt ist und schillert. Deshalb gilt auch von der Forderung der Entmythologisierung in besonders hohem Masse, was wir als Charakteristikum der ganzen Theologie BULTMANNS feststellen, nämlich dass sie mehrdeutig ist"83).

(3) Die geloof en die Heilsfeit (Heilstatsache): Dit is te waardeer dat BULTMANN die vraag: Wat beteken geloof in Jesus Christus? in al sy skerpte stel. Hier kan die volgende vrae gestel word: $:^{8 *}$ ) Word die objektiewe geloofsgrond by BULTMANN nie opgelos sodat slegs 'n subjektiewe gelowigheid oorbly nie? Het die geloof by hom nie geword tot 'n menslike immanente houding nie? Is BULTMANN nie besig om die teologie in 'n antropologie om te skep nie? ${ }^{85}$ ) Het die "Heilsgeschichte" nie sy karakter as werklikheid, as reële gebeure in ruimte en tyd verloor nie? $\left.{ }^{86}\right)$.

$\left.{ }^{80}\right)$ „Für und wider Bultmann”, do. bls. 21.

81) Emil Brunner: „Dogmatik", Band 2, Bls. 314.

82) „Für und wider die Theologie Bultmans". Bls. 28.

83) "Für und wider die Theologie Bultmanns", Bls. 27.

84) "Für und wider die Theologie Bultmans", bls. 30 en 31.

85) "Vgl. hier die 9de doktorale stelling van Dr. A. Szekeres. De Structuur van $\mathrm{E}$. Brunners Theologie. Diss. Utrecht 1953. 
Wat die geloof in die Heilsfeit by BULTMANN steur, is sy loëning van die opstanding van Jesus Christus. „Es ist nachweislich falsch, wenn BULTMANN die Absicht unterschoben wird, das Bekenntnis zu Jesus Christus als dem Auferstandenen zu streichen". ${ }^{87}$ ).

(4) Die invloed van BULTMANN in die praktyk: Die teologiese Fakulteit van Tübingen is bekommerd oor die uitwerking van BULTMANN se teologiese beskouing op die prediking en die gemeente. „Hier setzen die Klagen ein uber die zerstörende Einflusse, die von BULTMANNS Theologie auf die Studenten ausgehen, uber die zahlreichen Katastrophen im persönlichen Glaubens. leben junger Theologen"88).

Veelseggend is dit wanneer 'n hele Theologiese Fakulteit 'n waarskuwende stem laat hoor.

Van alle kante het teoloë in gesprek getree met BULTMANN. In Duitsland antwoord die eksegete ${ }^{8 \theta}$ ) en sistematiese teoloë ${ }^{90}$ ) met waardering en kritiek. BRUNNER en BARTH is voortdurend besig met die teologie van BULTMANN. In 1949 skryf die Vrye Universiteit van Amsterdam 'n prysvraag uit oor die „Entmythologisierung" van BULTMANN. Om die pro en contra argumente van die bogenoemde geleerdes ten opsigte van die „Entmythologisierung" ter sprake te bring sou 'n aparte studie vereis; ons doel is alleen om die sin en plek van die maagdelike geboorte van Jesus Christus soos dit in die teologiese gedagtegang van BULTMANN ingebed is krities van te stel. Ons het gevind dat dit as "legende", dit wil sê sonder historiese kern uitgeskil word; dat dit kragtens die "Entmythologisierung” in die sisteem van BULTMANN geen plek kan hê nie en derhalwe sinloos is. Dit

86) Emil Brunner: „Dogmatik” Band 2, bls. 314-315 wys Bultmann se opvatting van die Heilsgeskiedenis af: .,Es fehlt bei ihm durchgehends die Einsicht in die Bedeutsamkeit des neutestamentlichen epi hapax der Einmaligkeit des Christusereignisses, als eines Geschehens im historichen Kontinuum."

87) „Für und wider die Theologie Bultmanss" Bls. 35.

88) „Für und wider die Theologie Bultmanns" Bls. 37.

89) In die Bundel „Kerygma und Mythos" 1948, verskyn:

(a) Prof. D. Julius Schniewind: „Antwort an Rudolf Bultman”. ,Thesen zum Problem der Entmythologisierung".

(b) Prof. D. Dr. Ernst Lohmeyer: "Die rechte Interpretation des Mythologischen".

(c) Ein Briefwechsel van Prof. Dr. J. B. Soucek und P. Götz Harbsmeyer.

90) (d) Prof. D. Dr. Helmut Thielicke: „Die Frage der Entmythologisierung des N.T."

(e) Prof. D. Dr. F. K. Schumann: „Die Entmythologisier-barkeit des Christusgeschehens.

(f) P. Herman Sauer: „Die Definition des „Mythologische bei Bultman”. 
het sy plek in die Nuwe Testament eers later as 'n „christliche Zusatz" via die hellenistiese „omvorming” van die oorspronklike verkondiging gekry, dit wil sê wederregtelik.

In die twintigste eeu beweer Bultmann dat die maagdelike geboorte 'n latere „christliche Zusatz” is vanuit die Hellenisme. In die begin van die tweede eeu n.C. leer Ignatius die maagdelike geboorte as 'n vanselfsprekende deel van die christelike geloof. Vir Ignatius, wat vlak na die Nuwe Testamentiese tydvlak leef is dit geen idee of ' $n$ toevoeging van buite nie, maar ' $n$ feitelike werklikheid, nie 'n ,idee" nie maar 'n feit, 'n waarheid. Die "alēthós" van die patres in hierdie verband kan telkens onderstreep word. Bultmann kan, afgesien ook van die Nuwe Testament self, by die patres dus ook geen steun vind vir sy teorie van latere toedigting nie.

Bultmann wil soos die Modernisme die „mitologiese" uit die Evangelie uitsuiwer en het daarmee die kerugmatiese inhoud daarvan gevaarlik gaan snoei en geweld aangedoen. Die maagdelike geboorte is slegs een van hierdie lote wat uit die Nuwe Testamentiese boodskap uitgehaal moet word! 